\title{
Chromosomal imbalances detected in primary bone tumors by comparative genomic hybridization and interphase fluorescence in situ hybridization
}

\author{
Marcelo Razera Baruffi ${ }^{1}$, Edgard Edward Engel $^{2}$, Jeremy Andrew Squire ${ }^{3}$, Luis Gonzaga Tone ${ }^{1}$ \\ and Silvia Regina Rogatto ${ }^{4}$ \\ ${ }^{1}$ Departamento de Puericultura e Pediatria, Faculdade de Medicina, USP, Ribeirão Preto, SP, Brazil. \\ ${ }^{2}$ Departamento de Biomecânica, Medicina e Reabilitação do Aparelho Locomotor, Faculdade de Medicina, \\ USP, Ribeirão Preto, SP, Brazil. \\ ${ }^{3}$ Ontario Cancer Institute, Princess Margaret Hospital, University Health Network, Department of Medical \\ Biophysics, Department of Laboratory Medicine and Pathobiology, University of Toronto, ON, Canada. \\ ${ }^{4}$ Departmento de Genética, Instituto de Biociências, UNESP, Botucatu, SP, Brazil.
}

\begin{abstract}
We applied a combination of comparative genomic hybridization (CGH) and fluorescence in situ hybridization (FISH), to characterize the genetic aberrations in three osteosarcomas (OS) and one Ewing's sarcoma. CGH identified recurrent chromosomal losses at 10p14-pter and gains at 8q22.3-24.1 in OS. Interphase FISH allowed to confirm $8 q$ gain in two cases. A high amplification level of 11q12-qter was detected in one OS. The Ewing's sarcoma showed gain at 1p32-36.1 as the sole chromosome alteration. These studies demonstrate the value of molecular cytogenetic methods in the characterization of recurrent genomic alterations in bone tumor tissue.
\end{abstract}

Key words: comparative genomic hybridization, CGH, osteosarcoma, Ewing's Sarcoma.

Received: November 28, 2002; accepted: April 4, 2003.

\section{Introduction}

Recent technological advances in molecular genetics and cytogenetics have made it easier to identify some of the critical events associated with the development of cancer. Specific chromosome aberrations have been identified in some neoplastic diseases. The most remarkable progress has been achieved in hematological cancers. Knowledge concerning solid tumors is less advanced, which includes bone tumors. The Catalog of Chromosome Aberrations in Cancer (Mitelman et al., 2003) presently contains more than 42,600 karyotypically abnormal neoplasms. Osteosarcomas and Ewing's sarcomas account for less than $1 \%$ of these cases.

Osteosarcomas (OS) exhibit karyotypes with an unusually high degree of aneuploidy and structural rearrangements. Several reports using conventional cytogenetic analysis have revealed karyotypes with multiple numerical and complex structural rearrangements (Fletcher et al., 1994; Hoogerwerf et al., 1994; Lopez-Gines et al., 1996;

Send correspondence to Silvia Regina Rogatto. Departamento de Genética, Instituto de Biociências - UNESP, 14618-000 Botucatu, SP, Brazil. E-mail: rogatto@ ibb.unesp.br.
Bridge et al., 1997; Murata et al., 1998; Wolf et al., 1999; Boehm et al., 2000). The consensus findings, based on a number of classical cytogenetics surveys, are frequent structural alterations at chromosome bands or regions 1p11-13, 1q11-12, 1q21-22, 11p15, 12p13, 17p11-13, $19 \mathrm{q} 13$, and $22 \mathrm{q} 11-13$, and the common numerical abnormalities $+1,-9,-10,-13$, and -17 (reviewed in Boehm et al., 2000).

To address the inherent difficulties associated with conventional cytogenetic analysis, comparative genomic hybridization $(\mathrm{CGH})$ has been systematically applied to OS. Nine CGH studies of OS (Forus et al., 1995; Tarkkanen et al., 1995; Szymanska et al., 1996; Brinkschmidt et al., 1998; Tarkkanen et al., 1998, 1999; Mertens et al., 2000; Stock et al., 2000; Zielenska et al., 2001b) have identified frequent gains at chromosome arms 1q, 4q, 5p 7q, 8q, 14q, and chromosome 19, and losses at chromosome arms 2q, 3p, 6q, 8p, and 10p. Sites of high-level gain or amplification have been identified at 8q23-24 (Forus et al., 1995; Tarkkanen et al., 1995; Szymanska et al., 1996; Brinkschmidt et al., 1998; Tarkkanen et al., 1998; 1999; Mertens et al., 2000; Stock et al., 2000; Zielenska et al., 2001b), 12q12-q13 (Forus et al., 
1995; Szymanska et al., 1996; Tarkkanen et al., 1998), and 17p11-p12 (Lopez-Gines et al., 1996; Wolf et al., 1999; Zielenska et al., 2001b).

Ewing's sarcoma (ES) is the most frequent bone tumor in children under 10 years of age and the third most common primary malignant bone tumor in adults. Its characteristic alteration is $\mathrm{t}(11 ; 22)(\mathrm{q} 24 ; \mathrm{q} 12)$, which, in association with variant translocations involving $11 \mathrm{q} 24$ or $22 \mathrm{q} 12$, is described in $90 \%$ of the cases. Trisomies 8 (44\%) and 12 , and $\operatorname{der}(1 ; 16)$ leading to trisomy $1 \mathrm{q}$ have been described as additional changes. (Armengol et al., 1997). Thus, gains are much more frequent than losses. Armengol et al. (1997) studied Ewing's tumors by CGH and detected high-level amplifications in the 8q13-q24 and 1q regions, and minimal gains of the whole chromosomes 8 and 12, and 1q. Chromosomal aberrations acquired in addition to the ES rearrangements have been postulated to serve as markers for a more refractory disease (Kullendorff et al., 1999), specifically, gains in chromosomes 1q (Armengol et al., 1997), 8, and 12 (Maurici et al., 1998, Zielenska et al., 2001a), and deletions of the short arm of chromosome 1 (Hattinger et al., 2002). Other authors have shown that gains in the long arm of chromosome 1 resulting from an unbalanced translocation $\mathrm{t}(1 ; 16)$ have a negative impact on survival (Hattinger et al., 1999, 2002; Brisset et al., 2001). Polyploidy is also thought to be of prognostic value for predicting progressive disease or local recurrence, and karyotypes with additional structural chromosomal alterations are also considered to be associated with an unfavorable outcome (Kullendorff et al., 1999).

We studied four pediatric bone tumors (three osteosarcomas and one Ewing's sarcoma), not exposed to chemotherapy prior to the analysis, by CGH. To confirm or rule out chromosomal gains, FISH using 8q23 specific probes was used in two of the OS cases.

\section{Material and Methods}

\section{Patients and tumor specimens}

CGH was performed on three osteosarcomas and one Ewing's sarcoma obtained from the Department of Orthopedics (FMRP, USP- Ribeirão Preto, SP, Brazil) (Table 1). Immediately after surgery, the tumor samples were frozen at $-80{ }^{\circ} \mathrm{C}$ until extraction of high-molecular-weight DNA. Each sample was histopathologically evaluated to ensure the presence of at least $80 \%$ of tumor cells. Histopatho- logical classification was performed according to the WHO International Classification of Tumors (1990). None of the patients had undergone any kind of therapy prior to specimen collection. DNA was prepared using standard methodology with proteinase $\mathrm{K}$, extracted by phenol-chloroform, and precipitated with $100 \%$ ethanol. DNA samples were stored at $-20{ }^{\circ} \mathrm{C}$. Informed consent was obtained from all the patients prior to sampling.

\section{Comparative Genomic Hybridization (CGH)}

Metaphase spreads from normal lymphocytes were prepared using standard protocols. The slides were aged for 3-4 days prior to denaturation at $72{ }^{\circ} \mathrm{C}$ in $70 \%$ formamide/2XSSC, followed by dehydration in an ethanol series. Prior to hybridization, the slides were treated with $0.1 \mu \mathrm{g} / \mathrm{mL}$ proteinase $\mathrm{K}$ in $20 \mathrm{mM}$ Tris $\mathrm{pH} 7.5,2 \mathrm{mM} \mathrm{CaCl}_{2}$. CGH was performed according to a standard protocol (Kallioniemi et al., 1992) with some previously described modifications (Ojopi et al., 2001), using a QuipXL Genetics Workstation (Vysis, Downers Grove, IL, USA). The cut-off values for the fluorescence intensity ratio were set at 1.20 and 0.80 , with a $95 \%$ confidence limit. Mean ratio profiles were determined from the analysis of 9 to 12 metaphase cells. Gene amplification was defined as gain ratios $\geq 1.5$. The following regions were excluded from analysis: centromeres, acrocentric p-arms, telomeres, and heterochromatin-rich areas (Kallioniemi et al., 1994; Ojopi et al., 2001). In addition, "reverse labeling" by exchanging biotin and digoxigenin labeling of tumor and normal DNA was used.

\section{Fluorescence in situ hybridization (FISH)}

A tissue fragment from each of two OS samples was cultured for 5-8 days and processed for cytogenetic analysis, according to previously described procedures (Dracopoli, 2002). Control slides were made from phytohemagglutinin-stimulated normal male lymphoblasts. Sequences BAC RP1179E1 (ATCC \#59904, Rockville, MD) and chromosome 8 centromere $P M J 128$ were used as probes. The DNA probe BAC RP1179E1 was labeled with biotin-14-dATP (Gibco BRL) and the probe PMJ 128 was labeled with digoxigenin-11-dUTP (Gibco $\mathrm{BRL}$ ). Probe labeling, hybridization, suppression hybridization, detection, fluorescence microscopy and microphotography were performed as previously described (Rogatto et al., 1999). A minimum of 100 cells was evalu-

Table 1 - Clinical data on three osteosarcoma (OS) and one Ewing's sarcoma (ES) cases.

\begin{tabular}{lcll}
\hline Case & Sex/age (years) & Tumor Location & Follow-up /Outcome (August, 2002) \\
\hline FMRP2 (OS) & F/12 & osteosarcoma/ tibia left & alive after 7ys without recurrence \\
FMRP3 (OS) & F/3 & osteosarcoma/ humerus left & died of disease after 3ys with metastasis \\
FMRP4(OS) & M/14 & osteosarcoma/ femur right & died of disease after 2ys with metastasis \\
FMRP9 (ES) & $\mathrm{M} / 1$ & Ewing's sarcoma / fibula right & died of disease after 2ys with metastasis \\
\hline
\end{tabular}


ated in each cytogenetic sample, to assess the frequencies of losses or gains involving chromosome 8 .

\section{Results \\ Cytogenetics}

Clinical findings of the tumors are listed in Table 1. Chromosomal imbalances are summarized in Table 2, and Figure 1 illustrates the composite karyogram. Gains predominated over losses for all chromosomes. High copy-number amplification was observed at 11q12-qter in one OS sample (FMRP3). The three OS tumors had a common region of gain on chromosome 8 (8q22.3-24.1), although in two of them (cases FMRP2 and FMRP3) these gains were not significant at the $95 \%$ confidence limit. The most common losses were at 10p14-pter in two OS. The $\mathrm{CGH}$ results in ES revealed gain involving 1p32-36.1. The characteristic $\mathrm{t}(11 ; 22)$ was not detected in the ES tumor by RT-PCR methods (data not shown).

\section{Interphase FISH analysis of chromosome 8} centromere and 8q23.2

Since chromosome 8 was found to be the commonly gained chromosome in the OS samples, a more extensive analysis of this numerical change was performed by interphase FISH in cases FMRP2 and FMRP4. In Table 3 the proportion of nuclei exhibiting additional signals is in- dicated as a percentage of the total number of nuclei scored. Examples of the interphase FISH analysis are shown in Figure 1.

\section{Discussion}

Comparative genomic hybridization is a powerful genomic screening technique and has been widely used to analyze various tumors, including OS and ES. We used CGH and interphase FISH for direct analysis of three OS and one ES. The pattern of genomic alteration observed was consistent with previously published CGH data. The most frequent changes in OS were gains of $8 \mathrm{q} 22$, losses of 10p14-pter, and a high level of amplification at 11q12-qter.

Chromosome 8 has previously been found to show copy number changes, rearrangements, and amplifications in OS (Fletcher et al.2 1994; Hoogerwerf et al., 1994; Bayani et al., 2003), as well as in many other cancers (Knuutila et al., 1998, Mitelman et al., 2003, Veiga et al., 2003). Previous CGH analyses in OS have revealed the gain and/or amplification of 8q and loss of 8p (Forus et al., 1995; Tarkkanen et al., 1995; Szymanska et al., 1996; Brinkschmidt et al., 1998; Tarkkanen et al., 1998, 1999; Mertens et al., 2000; Stock et al., 2000; Zielenska et al., 2001b). In this study, chromosome 8 was found to be the most frequently involved in chromosomal aberrations. Three tumors had a common region of gain at 8q22.3-24.1. Using interphase FISH, we demonstrated the presence of

Table 2 - Chromosomal imbalances detected by CGH in three osteosarcomas (OS) and one Ewing's sarcoma (ES).

\begin{tabular}{lll}
\hline Cases & Losses $(\leq 0.80)$ & Gains $(\geq 1.20)$ \\
\hline FMRP2(OS) & $1 \mathrm{q} 43,8 \mathrm{p} 23.1$-pter, 10p14-pter, 19p13.3-pter & $1 \mathrm{q} 24-\mathrm{q} 25$ \\
FMRP3 (OS) & 3pter-qter, 9p12-q21, 10p14-pter & $11 \mathrm{q} 12-\mathrm{qter}(\mathrm{amp}), 8 \mathrm{q} 22.3-\mathrm{q} 24.1^{*}$ \\
FMRP4(OS) & $2 \mathrm{q} 35$-qter & $1 \mathrm{p} 13-\mathrm{p} 21,6 \mathrm{p} 11.2-\mathrm{p} 22,8 \mathrm{q} 11.2-\mathrm{q} 22.3,15 \mathrm{q} 22.1-\mathrm{q} 25,18 \mathrm{q} 12$ \\
FMRP9 (ES) & - & $1 \mathrm{p} 32-\mathrm{p} 36.1$ \\
\hline
\end{tabular}

*not significant at $95 \%$ confidence limit.

Table 3 - Interphase FISH analysis of chromosome 8 centromere copy number (probe PMJ 128) and gains at 8q23.2 (probe RPC 1179E1) in two osteosarcomas.

\begin{tabular}{|c|c|c|c|c|c|}
\hline \multicolumn{2}{|l|}{ Case FMRP2 } & \multicolumn{2}{|l|}{ Case FMRP4 } & \multicolumn{2}{|l|}{ Control } \\
\hline $\begin{array}{l}\text { Number of signals/nucleus } \\
\text { cen8/RP1179E1 }\end{array}$ & $\begin{array}{l}\text { Number of } \\
\text { cells (\%) }\end{array}$ & $\begin{array}{c}\text { Number of signals/nucleus } \\
\text { cen8/RP1179E1 }\end{array}$ & $\begin{array}{l}\text { Number of } \\
\text { cells (\%) }\end{array}$ & $\begin{array}{c}\text { Number of signals/nucleus } \\
\text { cen8/RP1179E1 }\end{array}$ & $\begin{array}{l}\text { Number of } \\
\text { cells }(\%)\end{array}$ \\
\hline $2 / 2$ & $19(38 \%)$ & $2 / 2$ & $35(26 \%)$ & $1 / 2$ & $16(10.7 \%)$ \\
\hline $2 / 3$ & $4(8 \%)$ & $2 / 3$ & $7(5.2 \%)$ & $2 / 2$ & $130(86.7 \%)$ \\
\hline $2 / 4$ & $19(38 \%)$ & $2 / 4$ & $15(11.1 \%)$ & $3 / 3$ & $4(2.7 \%)$ \\
\hline \multirow[t]{5}{*}{$2 / 4$} & $8(16 \%)$ & $2 />5$ & $17(12.6 \%)$ & & \\
\hline & & $3 / 3$ & $6(4.4 \%)$ & & \\
\hline & & $3 />6$ & $14(11.9 \%)$ & & \\
\hline & & $4 / 4$ & $16(11.19 \%)$ & & \\
\hline & & $4 />5$ & $25(2.1 \%)$ & & \\
\hline Total & 50 & & 135 & & 150 \\
\hline
\end{tabular}


A
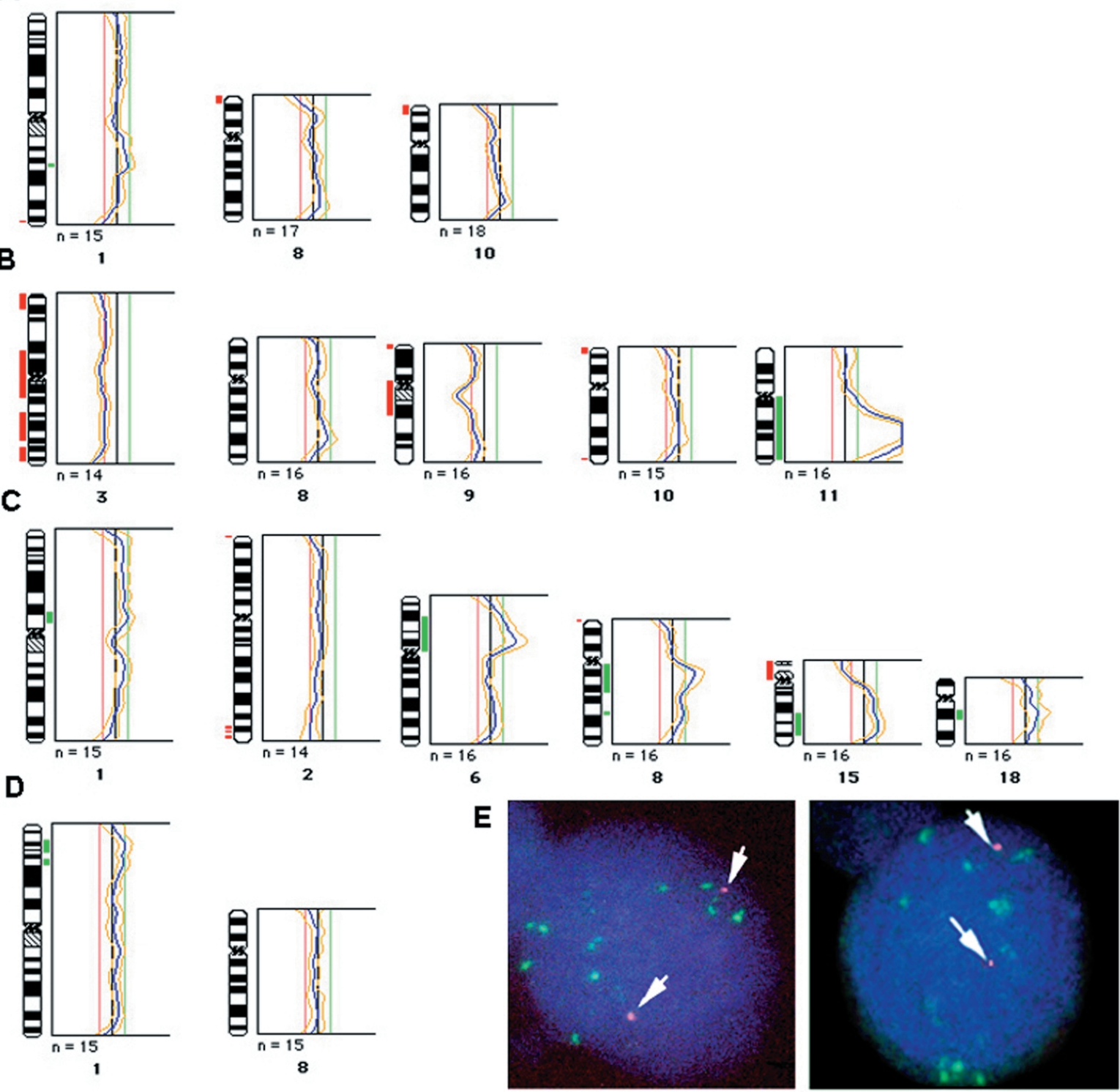

Figure 1 - Graphic representation of the CGH data obtained from three osteosarcomas and one Ewing's sarcoma. Bars on the right side of each chromosome denote gain, and on the left side loss of a sequence: (A) FMRP2, (B) FMRP3, (C) FMRP4, (D) FMRP9. (E) Interphase FISH in two OS (FMRP2 and FMRP4) confirming the presence of extra chromosome 8q23.2 sequence (green signals). The arrows indicate two signals for chromosome 8 centromere (red signals)

this amplification in two samples, although, by CGH, one of them showed a non-significant gain of 8q2. The combined approach of CGH and interphase FISH has greatly increased the ability to detect gains within the $8 \mathrm{q} 2$ region in OS.

Tarkkanen et al. (1999) reported that patients with tumors displaying a copy number increase at $8 \mathrm{q} 21.3-22$, $8 \mathrm{qcen}-\mathrm{q} 13$, and/or $1 \mathrm{q} 21$ are believed to show a trend toward short overall survival. In contrast, Stock et al. (2000) observed that, in 16 OS cases, copy number increases at $8 \mathrm{q}$ and 1q21 did not have an unfavorable impact on prognosis. Amplification of 8q, particularly involving the $C M Y C$ gene and its surrounding region at 8q24.1, has been described in breast, prostate, lung, colon, head and neck, gastric, acute myeloid leukemia, and brain tumors (Nesbit et al., 1999). In osteosarcoma, this genetic alteration has been described at variable frequencies (Ladanyi et al., 1993, Ueda et al., 1998, Gamberi et al., 1998). In a study on 27 OS, Ladanyi et al. (1993) found 7\% of CMYC amplification. In another study, CMYC expression appeared elevated in 9/21 (42\%) patients who relapsed, and in 4/17 (23\%) patients who remained disease-free (Gamberi et al., 1998). Recently, using FISH and CGH, Stock et al. (2000) demonstrated the presence of two distinct 8q loci involved in the pathogenesis of OS, one located more proximally at $8 \mathrm{q} 21$, the other more distally at $8 \mathrm{q} 23-24.1$. Three tumor samples displayed only 
gain of 8q23 sequences, without involvement of the $C M Y C$ oncogene, as verified by FISH (Stock et al., 2000). Tsuneizumi et al. (2001) described an overrepresentation of the EBAG9 gene, $C M Y C$, or both, in 58/129 breast tumors. The $E B G 9$ gene was increased exclusively in $16 / 27$ tumors showing gains at $8 \mathrm{q} 23$. This estrogen-responsive gene was found to be identical to RCSA1, a cancer cell-surface antigen implicated in immune escape. We used the RP11-79E1 genomic probe for FISH analysis, mapped at $8 \mathrm{q} 23$, where the $E B A G 9$ gene is located. Since $8 \mathrm{q} 22.3-24.1$ is the minimal commonly amplified region in $\mathrm{OS}$, there are at least three potential candidate genes: $C M Y C, T N F R S F 11 B$ (this protein is an osteoblast-secreted decoy receptor that functions as a negative regulator of bone re-absorption), and $E B A G 9$. However, this region is large, and it is hard to determine which specific gene(s) could confer a selective driving force, as copy number increases are acquired during OS tumorigenesis.

Amplification of chromosome band 11q12-qter has been found in OS previously (Stock et al., 2000; Zielenska et al., 2001b). Gene amplification is one of the pathways leading to activation of protooncogenes, which may contribute to tumor progression. The identification of amplified genes in tumor cells thus contributes to the understanding of the neoplastic process. We detected DNA amplification of 11q12-qter in OS case. This region includes the cyclin D1 gene, mapped to 11q13. Maelandsmo et al. (1995) found high CCND1 expression by Northern analysis in $22 \%$ of osteosarcomas, and cyclin D1 amplification in 4\%. Wei et al. (1998) found elevated cyclin D1 expression by immunohistochemistry in only $4 \%$ of cases. In addition, in head and neck tumors, amplification of this region has been associated with a higher metastatic potential (Muller et al., 1994). Case FMRP3 with amplification of $11 \mathrm{q}$ in addition to gain at 8q11.2-22.3 and 1p13-21, had a poor survival; the patient died of the disease, after 2 years with metastasis. Further studies on these specific high-level amplification regions are necessary to identify the oncogenes which play crucial roles in tumor initiation and/or tumor progression of different OS subsets.

In our study, two OS cases had losses involving 10p14-pter. Recently, Baruffi et al. (2002) reported deletions involving 10p13-pter in three cases of giant-cell bone lesions. There are 66 genes or hypothetical genes mapped to this region (http://cgap.nci.nih.gov/Genes/GeneFinder), including DNMT2 (DNA cytosine-5- methyltransferase 2), located at 10p15.1. Recently, Schultz et al. (2002) found an association between DNA hypomethylation and chromosome 8 aberrations (loss at $8 \mathrm{p}$ and gain at $8 \mathrm{q} 21$ and $8 \mathrm{q} 23$-qter) in prostate cancer. The chromosomal alteration and DNA hypomethylation tended to be frequent in higher-stage tumors and associated with the presence of metastases. The authors suggest that hypomethylation facilitates this particular chromosomal change. Similarly, it is conceivable that the loss of the DNMT2 gene at $10 \mathrm{p}$ is re- lated to hypomethylation, and, in association with gain at $8 \mathrm{q}$, contributes to progression of the OS.

Ewing's sarcoma is the most frequent bone tumor in children under 10 years of age, and the third most common primary malignant bone tumor in adults. The case studied by us was re-evaluated by two pathologists and classified as belonging to the Ewing family of tumors based on histology and staining for the MIC2 gene product. Reverse transcriptase-polymerase chain reaction (RT-PCR) indicated that this tumor was negative for the presence of the ES-specific chromosomal abnormality $\mathrm{t}(11 ; 22)(\mathrm{q} 24 ; \mathrm{q} 12)$. It is thus possible that it underwent a variant translocation of the EWS gene, leading to fusion transcripts with $E S$ family members such as $E R G$ on chromosome 21q22, or ETV1 at $7 \mathrm{p} 22$, or $E 1 A F$ at $17 \mathrm{q} 12$, or $F E V$ at $2 \mathrm{q} 23$. Other chromosomal abnormalities, without the specificity of the primary change, have repeatedly been detected in ES (reviewed in Sandberg and Bridge, 2000). In the majority of ES cases described, a net imbalance involving gain of 1q with simultaneous loss of 16q is reported (Sandberg and Bridge, 2000; Mitelman et al., 2003). However, we detected gain at 1p32-p36.1 as the sole chromosomal abnormality in an ES from a one-year-old patient. Loss of $1 \mathrm{p} 36$ has been associated with poor outcome in Ewing's sarcoma (Hattinger et al., 1999). Obviously, the small sample size in the present study does not allow a conclusion to be drawn.

Further studies are required increasing the sample size and evaluating the exact extension of the aberrations by FISH with locus-specific probes in order to define the genes involved in gains and losses detected by $\mathrm{CGH}$, in particular losses at 10p and gains at $8 \mathrm{q}$ in OS.

\section{Acknowledgments}

We thank to Luciana CS Veiga and Rosane GP Queiroz for technical assistance. We are grateful to José Alexandre Lemos Reis for assistance in collecting samples. This research was supported by FAPESP and CNPq.

\section{References}

Armengol G, Tarkkanen M, Virolainen M, Forus A, Valle J, Bohling T, Asko-Seljavaara S, Blomqvist C, Elomaa I, Karaharju E, Kivioja AH, Siimes MA, Tukiainen E, Caballin MR, Myklebost O and Knuutila S (1997) Recurrent gains of 1q, 8 and 12 in the Ewing family of tumours by comparative genomic hybridization. $\mathrm{Br} \mathrm{J}$ Cancer 75:1403-1409.

Baruffi MR, Barbieri-Neto J, Pina-Neto JM, Suerzut CE and Casartelli C (2002) Distinct nonrandom patterns of chromosomal deletions in giant-cell lesions of bone. Genet Molec Biol 25:265-270.

Bayani J, Zielenska M, Pandita A, Al-Romaih K, Karaskova J, Harrison K, Bridge JA, Sorensen P, Thorner P and Squire JA (2003) SKY identifies recurrent complex rearrangements of chromosomes 8, 17, and 20 in osteosarcomas. Genes Chromosomes Cancer 36:7-17. 
Boehm AK, Squire JA, Bayani J, Nelson M, Neff J and Bridge JA (2000) Cytogenetic findings in 35 osteosarcoma specimens and a review of the literature. Ped Pathol Molec Med 19:359-376.

Bridge JA, Nelson M, Mccomb E, Mcguire MH, Rosenthal H, Vergara G, Maale GE, Spanier S and Neff JR (1997) Cytogenetic findings In 73 osteosarcoma specimens and a review of the literature. Cancer Genet Cytogenet 95:74-87.

Brinkschmidt C, Blasius S, Burger H, Simon R, Diallo R, Battmann A, Winkelmann W, Bocker W and Dockhorn-Dworniczak B (1998) Comparative genomic hybridization $(\mathrm{CGH})$ for detecting a heretofore undescribed amplified chromosomal segment in high-grade medullary osteosarcoma. Verh Dtsch Ges Pathol 82:184-188.

Brisset S, Schleiermacher G, Peter M, Mairal A, Oberlin O, Delattre O and Aurias A (2001) CGH analysis of secondary genetic changes in Ewing tumors: correlation with metastatic disease in a series of 43 cases. Cancer Genet Cytogenet 130:57-61.

Dracopoli NC (2002) Current Protocols in Human Genetics. New York, USA, John Wiley \& Sons, Inc (CD version).

Fletcher JA, Gebhardt MC and Kozakewich HP (1994) Cytogenetic aberrations in osteosarcomas. Nonrandom deletions, rings, and double-minute chromosomes. Cancer Genet Cytogenet 77:81-88.

Forus A, Weghuis DO, Smeets D, Fodstrad O, Myklebost O and Geurts van Kessel A (1995) Comparative genomic hybridization analysis of human sarcomas: II Identification of novel amplicons at $6 p$ and $17 p$ in osteosarcomas. Genes Chromosomes Cancer 14:15-21.

Gamberi G, Benasi MS, Bohling T, Ragazzini P, Molendini L, Sollazano MR, Pompetti F, Merli M, Magagnoli G, Balladelli A and Picci P (1998) c-MYC and FOS in human osteosarcoma. Prognostic value of mRNA and protein expression. Oncology 55:556-563.

Hattinger CM, Rumpler S, Strehl S, Ambros IM, Zoubeck A, Potschger U, Gadner H and Ambros PF (1999) Prognostic impact of deletions at $1 \mathrm{p} 36$ and numerical aberrations in Ewing tumors. Genes Chromosomes Cancer 24:243-254.

Hattinger CM, Potschger U, Tarkkanen M, Squire J, Zielenska M, Kiuru-Kuhlefelt S, Kager L, Thorner P, Knuutila S, Niggli FK, Ambros PF, Gadner H and Betts DR (2002) Prognostic impact of chromosomal aberrations in Ewing tumours. Brit J Cancer. 86:1763-1769.

Hoogerwerf WA, Hawkins AL, Perlman EJ and Griffin CA (1994) Chromosome analysis of nine osteosarcomas. Genes Chromosomes Cancer 9:88-92.

Kallioniemi A, Kallioniemi OP, Sudar D, Rutovitz D , Gray JW, Waldman F and Pinkel D (1992) Comparative genomic hybridization for molecular cytogenetic analysis of solid tumors. Science 258:818-821.

Kallioniemi PO, Kafllioniemi A, Piper J, Isola J, Waldman FM,Gry JW and Pinkel D (1994) Optimizing comparaive genomic hybridization for analysis of DNA sequence copy number changes in solid tumors. Genes Chromosomes Cancer 10:231-243.

Kullendorff CM, Mertens, Donner M, Wiebe T, Akerman M and Mandahl N (1999) Cytogenetic aberrations in Ewing sarcoma: are secondary changes associated with clinical outcome? Med Ped Oncol 32:79-83.
Knuutila S, Aalto Y, Autio K, Björkqvist A-M, El-Rifai E, Hemmer S, Huhta T, Kettunen E, Kiuru-Kuhlefelt S, Larramendy ML, Lushnikova T, Monni O, Pere H, Tapper J, Tarkkanen M, Varis A, Wasenius VM, Wolf M and Zhu Y (1999) DNA copy number losses in human neoplasms. Am J Pathol 155:683-694.

Ladanyi M, Parck CK, Lewis R, Jhanwar SC, Healey JH and Huvos AG (1993) Sporadic amplification of the MYC gene in human osteosarcomas. Diag Mol Pathol 2:163-167.

Lopez-Gines C, Carda-Batalla C, Lopez-Terrada L and Llombart-Bosch A (1996) Presence of double minutes and monosomy $17 \mathrm{p}$ in xenografted human osteosarcomas. Cancer Genet Cytogenet 90:57-62.

Maelandsmo GM, Berner JM, Florenes VA, Forus A, Hovig E, Fodstad O and Myklebost O (1995) Homozygous deletion frequency and expression levels of the CDKN2 gene in human sarcomas. Relationship to amplification and mRNA levels of CDK4 and cyclin D1. Br J Cancer 72:393 398.

Maurici D, Perez-Atayde A, Grier HE, Baldini N, Serra M and Fletcher JA (1998) Frequency and implications of chromosome 8 and 12 gains in Ewing sarcoma. Cancer Genet Cytogenet 100:106-110.

Mertens F, Larramendy M, Gustavsson A, Gisselsson D, Rydholm A, Brosjo O, Mitelman F, Knuutila S and Mandahl N (2000) Radiation-associated sarcomas are characterized by complex karyotypes with frequent rearrangements of chromosome arm 3p. Cancer Genet Cytogenet 116:89-96.

Mitelman F, Johansson B and Mertens F (2003) Mitelman Database of Chromosome Aberration in Cancer. Mitelman F, Johansson B, Mertens F (eds). http://cgap.nci.nih.gov/Chromosomes/Mitelman.

Muller D, Millon R, Lidereau R, Eengelmann A, Bronner G, Flesh H, Eber M, Methlin G and Abecassis J (1994) Frequent amplification of 11q13 DNA markers is associated with lymph node involvement in human head and neck squamous cell carcinomas. Eur J Cancer B Oral Oncol 30B: 113-120.

Murata H, Kusuzaki K, Takeshita H, Hirasawa Y, Ashihara T, Abe T and Inazawa J (1998) Aberrations of chromosomes 1 and 17 in six human osteosarcoma cell lines using double-target fluorescence in situ hybridization. Cancer Genet Cytogenet 107:7-10.

Nesbit CE, Tersak JM and Prochownik EV (1999) MYC oncogenes and human neoplastic disease. Oncogene 18:30043016.

Ojopi EPB, Rogatto SR, Caldeira JRF, Barbieri-Neto J and Squire JA (2001) Comparative genomic hybridization detects novel amplifications in fibroadenomas of the breast. Genes Chromosomes Cancer 30:25-31.

Rogatto SR, Rainho CA, Zhang ZM, Figueiredo F, Barbieri-Neto J, Georgetto SM and Squire JA (1999) Hemangioendothelioma of bone in a patient with a constitutional supernumerary marker. Cancer Genet Cytogenet 110:23-27.

Sandberg AA and Bridge JA (2000) Updates on cytogenetics and molecular genetics of bone and soft tissue tumors: Ewing sarcoma and peripheral primitive neuroectodermal tumors. Cancer Genet Cytogenet 123:1-26.

Schulz WA, Elo JP, Florl AR, Pennanen S, Santourlidis S, Engers R, Buchardt M, Seifert HH and Visakorpi T (2002) Genomewide DNA hypomethylation is associated with alterations on chromosome 8 in prostate carcinoma. Genes Chromosomes Cancer 35:58-65. 
Stock C, Kager L, Fink FM, Gadner H and Ambros PF (2000) Chromosomal regions involved in the pathogenesis of osteosarcomas. Genes Chromosomes Cancer 28:329-336.

Szymanska J, Mandahl N, Mertens F, Takkanen M, Karaharju E and Knuutila S (1996) Ring chromosomes in parosteal osteosarcoma contain sequences from 12q13-15: a combined cytogenetic and comparative genomic hybridization study. Genes Chromosomes Cancer 16:31-34.

Tarkkanen M, Bohling T, Gambieri G, Ragazzini P, Benassi MS, Kivioja A, Kallio P, Elomaa I, Picci P and Knuutila S (1998) Comparative genomic hybridization of low-grade central osteosarcoma. Mod Pathol 11:421-426.

Tarkkanen M, Elomaa I, Blomqvist C, Kivioja AH, KillokumpuLehtinen P, Bohling T Valle J and Knuutila S (1999) DNA sequence copy number increase at 8q: a potential new prognostic marker in high-grade osteosarcoma. Int $\mathrm{J}$ Cancer 84:114-121.

Tarkkanen M, Karhu R, Kallioniemi A, Elomaa I, Kivioja A, Nevalainen J, Bohling T, Karaharju E, Hyytinen E and Knuutila S (1995) Gains and losses of DNA sequences in osteosarcomas by comparative genomic hybridization. Cancer Res 55:1334-1338.

Tsuneizumi M, Emi M, Nagai H, Harada H, Sakamoto G, Kasumi F, Inoue S, Kazui T and Nakamura Y (2001) Overrepresentation of the EBAG9 gene at 8q23 associated with early-stage breast cancers. Clinical Cancer Res 7:35263532 .
Ueda T, Healey JH, Huvos AG and Ladanyi M (1998) Amplification of the MYC gene in osteosarcoma arising in Pagets disease. Sarcoma 1:131-134.

Veiga LCS, Bérgamo NA, Reis PP, Kowalski LP and Rogatto SR (2003) DNA gain at 8q23.2: a potential early marker in head and neck carcinomas. Cancer Genet Cytogenet (in press).

Wei G, Lonardo F, Ueda T, Kim T, Huvos AG, Healy JH and Ladanyi M (1998) CDK4 gene amplification in osteosarcoma: reciprocal relationship with INK4A gene alterations and mapping of 12q13 amplicons. Int J Cancer 80:199-204.

Wolf M, Tarkkanen M, Hulsebos T, Larramedy ML, Forus A, Myklebost O, Aaltonen LA, Elomaa I and Knuutila S (1999) Characterization of the $17 \mathrm{p}$ amplicon in human sarcomas: microsatellite marker analysis. Int J Cancer 82:329-333.

World Health Organization (1990) International classification of diseases for oncology, 2nd ed., Geneva: World Health Organization.

Zielenska M, Bayani J, Pandita A, Toledo S, Marrano P, Andrade J, Petrilli A, Thorner P, Sorensen P and Squire JA (2001a) Comparative genomic hybridization analysis identifies gains of 1p35-36 and chromosome 19 in osteosarcoma. Cancer Genet Cytogenet 130:14-21.

Zielenska M, Zhang ZM, Ng K, Marrano P, Bayani J, Ramirez OC, Sorensen P, Thorner P, Greenberg M and Squire JA (2001b) Acquisition of secondary structural chromosomal changes in pediatric Ewing sarcoma is a probable prognostic factor for tumor response and clinical outcome. Cancer 91:2156-2164. 